Title: "This is Father Berrigan Speaking from the Underground": Daniel Berrigan SJ and the Conception of a Radical Theatre

Author Name: Benjamin Halligan

Affiliation: University of Wolverhampton

Postal address:

Dr Benjamin Halligan

Director of the Doctoral College

Research Hub - MD150g, Harrison Learning Centre

City Campus South, University of Wolverhampton

Wulfruna Street, Wolverhampton WV1 1LY

United Kingdom

B.Halligan@wlv.ac.uk

01902322127 / 07825871633

Abstract:

The letter "Father Berrigan Speaks to the Actors from Underground" suggests the conception of a radical theatre, intended as a contribution to a cultural front against the US government during a time of the escalation of the war in Vietnam. The letter was prepared further to Berrigan's dramatization of the trial in which he and fellow anti-war activists were arraigned for their public burning of draft cards in 1968. The play was the Trial of the Catonsville Nine and its production coincided with a period in which Berrigan, declining to submit to imprisonment, continued his ministry while a fugitive.

Keywords: Daniel Berrigan, underground, Jesuit, Catonsville, anti-war, theatre, counterculture, spirituality, activism, Living Theatre.

Biographical note:

Dr Benjamin Halligan is Director of the Doctoral College of the University of Wolverhampton. Publications include Michael Reeves (Manchester UP, 2003), Desires for Reality: Radicalism and Revolution in Western European Film (Berghahn, 2016), and the co-edited collections Mark E. Smith and The Fall: Art, Music and Politics (Ashgate, 2010), Reverberations: The Philosophy, Aesthetics and Politics of Noise (Continuum, 2012), Resonances: Noise and Contemporary Music (Bloomsbury Academic, 2013), The Music Documentary: Acid Rock to Electropop (Routledge, 2013), and The Arena Concert: Music, Media and Mass Entertainment (Bloomsbury Academic, 2015). 
"This is Father Berrigan Speaking from the Underground": Daniel Berrigan SJ and the Conception of a Radical Theatre Benjamin Halligan

Activist, academic, poet, playwright, Jesuit priest and public performer Daniel Berrigan, SJ, died on 30 April 2016. He was nearly 95 years old. His passing reawakens the vital work he did during the 1960 s in opposition to the Vietnam War. Father Berrigan remained an anti-war activist (speaker, organiser and protestor), as well ministering to AIDs patients and fighting to raise AIDs awareness, right up until his death. At 92, Berrigan took part in Occupy protests at New York's Zuccotti Park.

"Father Berrigan Speaks to the Actors from Underground" is, relative to Daniel Berrigan's very substantial body of published writing across more than fifty years, only a fragment, and something of an incidental fragment in terms of its seemingly limited concerns. It is nominally a letter to the actors and audiences involved in the production of his play The Trial of the Catonsville Nine. "To the Actors..." was first published in the public domain, in an edited form, in The New York Times on 31 January 1971 and, in full, in America 
is Hard to Find: Notes from the Underground and Letters from Danbury Prison in 1972, a collection of writings mostly from Berrigan's four months "on the run" from the Federal Bureau of Investigations. ${ }^{1}$ Such writing came from a period of "underground" existence on Berrigan's part. An earlier collection of his writings from this period, The Dark Night of Resistance, which appeared in 1971, begins with a section dated April 1970 and "I start these notes quite literally on the run" (Berrigan 1971: 1). Berrigan, apparently on the FBI's list of the ten "Most Wanted" fugitives, was captured in theologian William Stringfellow's cottage on Block Island, Rhode Island in August 1970, by FBI agents posing as birdwatchers. He was imprisoned for two years of his three year sentence in Danbury prison in Connecticut. ${ }^{2}$ Berrigan was one of a number of figures that Meconis (1979) identifies as the "Catholic Left" who, to further nonviolent political (mostly anti-war) activism, went underground at this time. In 1970, Berrigan referred to his position as one of "felonious vagrancy" (1973: 60) .

Berrigan's fugitive period arose from his first arrest, trial, and successful prosecution for his central involvement in the public burning in Catonsville, Maryland, on 17 May 1968 - using homemade napalm (gasoline mixed with Ivory Flakes soap powder) - of 600 stolen 1-A draft records of North Americans conscripted to fight in Vietnam. The film footage of this 
event reveals the small activist group (which included Daniel's brother Philip, a Josephite Roman Catholic priest, writer, and activist) calmly, even apologetically, undertaking their action. The event seems to be a prayer meeting complete with religious invocations (spontaneous articulations and well-known prayers) from those involved, standing in semicircle, speaking in turn. ${ }^{3}$ In this respect, the event is seemingly more than just activism: it is affective in that it seeks divine acknowledgement and aid. And although the actionspectacle had a profound symbolic value, showing clerics engaged in illegal anti-war activities, the event was more than symbolic: burning the cards disrupted, even if only modestly, the process of the "war effort". The footage of the action was introduced as evidence into the subsequent trial and reproduced in an early production of The Trial of the Catonsville Nine (see O'Connor, 2013: 27 and 34 respectively). The act gestured to the possibility of further such actions so that for Brown, the vexatious matter of "The Berrigans" at this juncture was the question "Signs or Models?" (Brown 1971: 60-70). For the Milwaukee Fourteen, associated with the Catholic Worker organization and including a Benedictine priest, who torched 10,000 draft cards on 24 september 1968 (see Klejment 1988: 285), the answer was clearly "models." The Catonsville action was an example that extended beyond just Catholics, as Klejment notes, to fifty other such instances (1988: 277). Meconis notes that the Trappist monk and writer 
Thomas Merton was uneasy with the event, seemingly finding in this nonviolent protest a problematic overlap with "the language of power" - an overlap, that is, with those who would engage in destructive violent protest or state violence (1979: 36-38). Reflecting on Catonsville in 1975 - on the other side of his jail term - Berrigan opted for the term "resistance" to describe the action, effectively affiliating it with a wider counterculture of resistance that had become, as he acknowledged, "very important around 1967 in the States" (Hạn and Berrigan 2001: 128). This resistance challenged the war in Vietnam by asking American citizens to act to end it.

Berrigan's The Trial of the Catonsville Nine, which dramatized the trial of 5-9 October 1968, was written in 1969 and first published in 1970. Early theatrical productions included those by the Center Theatre Group at the Mark Taper Forum in Los Angeles, in the "New Theater for Now" series, directed by Gordon Davidson, in August 1970; at Good ShepherdFaith Church in New York in January 1971 by the Phoenix Theater Company; an amateur production at Boston University, directed by Valerie Hendy; and at the Lyceum Theatre in New York in June 1971. O'Connor summarizes the production history (2013: 192, footnote 25) noting at least two public readings of the play in Los Angeles in 1970-71 (2013: 193, footnote 46), as well as legal action mounted against a performance by the Citizens Legal Defense Alliance (2013: 34-35). Crow 
recalls a production from around this time in which audience members were picked "to participate in a mock jury" (Crow 1996: 67). For the Phoenix Theater production, the set appropriated the altar area of the Good Shepherd-Faith Church, with the Judge positioned in the pulpit: an "intersection of church, theatre, and courtroom" (O'Connor 2013: 39). Here too the audience acted as jury. For o'Connor "[t]his theatrical event about religious activists who challenge the secular power of the law combines the physical markers from three distinct institutional gathering places; this intersection of the three serves as a reminder that all these gathering places normally exist in separate spheres but all function as sites for acting out ritualistic cultural practices" (O'Connor 2013: 39). From the outset, then, the play's production was perceived as a political act.

The play won two Obies in 1971, for distinguished production and distinguished direction (for Gordon Davidson), for the June 1971 run in the Lyceum Theatre. A double LP version, in a version Gordonson staged for audio recording with the Center Theatre Group, was produced by Caedmon in 1971. An East German television film adaptation, Der Prozess gegen die Neun von Catonsville, directed by Hans-Erich Korbschmitt, was broadcast in March 1972, and a US feature film -- adapted by Berrigan, directed by Davidson, and 
produced by Gregory Peck -- The Trial of the Catonsville Nine, was released in 1972 .

While the play very directly invites a consideration of its autobiographical nature, "To the Actors..." suggests something more. That is - that the theatrical event itself was part of a continuum of activism comprising a solidarity between fugitive or imprisoned activists and the play's audiences. And these connections, as contextualized in "To the Actors...", were to be made between the "overground" of free citizens and the "underground" of the hunted activists.

\section{To the Underground}

Daniel Berrigan, his brother, and some of their associates vanished just before their sentences were due to begin. One associate, Mary Moylan (1936-1995), sentenced to two years, remained underground for nearly a decade before surrendering to the authorities in 1979. Berrigan noted in 1970 (in "Letter to the Jesuits") that his intention was to "surrender to Caesar", "when my point is made and the good of the community has been served" (Berrigan 1973: 37). Going underground was at the time more associated with groups such as the Symbionese Liberation Army and the Weather Underground, who were waging an armed struggle against the American state. ${ }^{4}$ In Berrigan's case, going underground is perhaps better considered in relation to another tendency: a gentle exiting from the mainstream of life. In this respect, in the 
terminology of the times, the move was akin to "going back to the country" or "getting it together in the country," or rejecting city life in favor of commune life where people could create what which sociologist Ron E. Roberts explored as "an alternative society" (1971: 1); or using the road trip as a way to become reacquainted with a country that had seemingly lost its way - as in Simon and Garfunkel's 1968 song "America or Dennis Hopper's 1969 film Easy Rider. Thus Berrigan's move was of a piece with those who encountered the need to abandon their professional commitments, as with Peter Jenkins, who dropped out of his job in 1973 in order to walk across America. Jenkins wished to leave an existence that was intractably beset by the ethical and existential burden of imperial wars abroad, widespread drug addiction at home, impending ecological/nuclear disasters, loveless bourgeois life, and aggression against resisters ([1979] 1983: 24-25). Jenkins' Damascene moment:

When I got home from work that summer day [of 1973], I called Cooper [Jenkins' half Alaskan malamute] and we went for a long meditative walk [...] I made a decision about what we would do. Cooper and I were going to walk about the U.S.A. That's right! We were going to give this country one last chance (Jenkins 1983: 26-27). 
Jenkins' A Walk Across America could suitably have been subtitled the same as Berrigan's collection of writing from the underground, America is Hard to Find.

And walking, movement - a proactive, physical encounter with the world - was the condition of spiritual existence for Berrigan. Spiritual existence is not exclusively identified with a withdrawal into otherworldliness and the notion of the world as a "veil of tears," in keeping with general Catholic tendencies of the pre-Vatican II era. Spiritual existence is reconfigured, along existential lines, and so becomes the very method of rediscovering ordinary lives.

Berrigan found a striking parallel to his joining the underground in Pier Paolo Pasolini's Christ in Il Vangelo secondo Matteo (The Gospel According to St Matthew, 1964): "Jesus is always in motion; He teaches while He's walking with His friends [...] So much 'sacred' art has snuffed out the spirit of Jesus. He sits there in heavenly rest, tossing [to "his friends"] words which they accept passively. But in Pasolini's movie there's a kind of uneasy motion [...]. The same physical effort required to stay with Him on the road is required to stay with Him in spirit." (Hạnh and Berrigan 2001: 147-148) The potential of "opening up" spiritual activities outside the institutions, dogma, and rituals of the church was much in the air in the late 1960s. Christian radicals were a major bloc in the commune phenomenon. Even the record company 
executive Stan Cornyn was emboldened to articulate such a theological sentiment for the sleeve notes of the 1968 psychedelic LP Mass in F Minor by The Electric Prunes: "So much in the old cathedral seemed, to the young man, intent on making him feel smaller. [...] Christian worship has been graven on granite and vested in shining robes and danced in jungles and shared on lake shores. [...] Christian worship has forms as many as the creative energies of Man. [sic] The Mass in F Minor is one of these." ${ }^{5}$

For Jenkins and Berrigan, dropping out is not just a radical refusal of bourgeois society, or a full embrace of hedonism, or an "off the grid" self-sufficiency. Rather, it was active mobilization: dropping into the day-to-day realities of citizens, initiating encounters with ordinary people, empathizing with their daily struggles, and strategizing how to alleviate oppression. In the documentary Father Daniel Berrigan: The Holy Outlaw (Lee Lockwood and Don Lenzer, 1970), ${ }^{6}$ footage from the underground period depicts Berrigan reflecting on his fugitive status:

Voice-over: [...] During the time he was in hiding, Father Berrigan changed his location often. He stayed with 37 different families in ten Eastern and Midwestern cities. Ten days prior to his arrest, Father Berrigan was interviewed by Lee Lockwood for NET in an underground location, in an apartment in New York City. 
Lockwood (off-camera): Father Dan, you've been

underground for some time now. What's it like to be underground in the United States of America?

Berrigan: All I can say is that it looks like it could go on forever. It looks good enough - looks useful enough for the movement. I think it's been an enormous opportunity to work up-close with people, with small groups, to meet with the media, to reflect and meditate, to do a great deal of reading - in fact, to do everything that I was doing before but to do it squared: to do it twice as intensely, twice as much.

Existence underground, for Berrigan, is close to a retreat and indeed, he goes on to note, breaking cover affords him the opportunity to continue his formal ministry with ever-greater mindfulness. "I'm going to preach in a church, in an urban church. [...] I want to be with a group of worshipping Christians, not necessarily Catholics, and I want to refer to the New Testament, and I want us to relate it to what we've done."7 After all, this is not a case of him situating himself in the underground, but rather - as the letter/article has it, - speaking "from Underground". The precision of this position was articulated in relation to a political strategy: "an attempt to create an underground presence which will be nonviolent and politically audible" (Berrigan 1973: 54). The sermon that follows - also in the film - includes Berrigan 
noting "We have chosen to be branded as 'peace criminals' by war criminals." He later notes a "Jesuit underground" and relates this to suppression of clerics in Elizabethan England and Soviet Russia. In Dark Night of Resistance, the underground status is presented as answering an unavoidable question: "How are we to live our lives today? We are in the dark preliminary stages of a new humanity, together." (1971: 6)

The paradox in this shift from over- to underground is that spiritual reflection is occurring from a position of active resistance - so that the two are entwined - rather than as divorced and distanced; spiritual reflection can arise only once the individual is unencumbered from the trivial engagements with the world (as in, for example, a monastic life). For Bianchi the paradox in Berrigan's case was a matter of "uncover[ing] the fundamentally worldly core of a professional religious figure" (Bianchi 1972: 55). This paradox is not lost on Berrigan who, writing from underground, extended this inversion, observing that "[t]he time will shortly be upon us, if it is not already here, when the pursuit of contemplation becomes a strictly subversive activity. This is the deepest and at the same time, I think, the most sensible way of expressing the trouble into which my brother and I have fallen" (Berrigan 1973: 77). Berrigan's underground text of choice for this period is The Dark Night 
of the Soul by st. John of the Cross which becomes a subject of his meditation carried out at one point "in someone's attic room" (1971: 7, 19, 178). St. John was a back-pocket companion to essential (for activists) battered paperbacks of writing by Lenin, Gramsci, Guevara, and Marx. ${ }^{8}$ It is this paradox that is the essential context for "To the Actors...": a communique akin to the Weather Underground's rather than the standard clerical sermon. But being on a spiritual retreat contrasts sharply with Berrigan's actual resistance: the Catonsville fire was lit while he was "at work," it was part of his priestly job. One should differentiate then between fugitive-resistance (the underground where, necessarily, all actions are disapproved of) and straight resistance (the over-ground, in which action mounted in respect to a position in society are presented as part of one's civic duty). And indeed not to be underground is akin to Berrigan's recollection of Merton commenting to him that "I am already dead, dead [...]" (1971: 180), as if Merton's respectability had fatally eroded his earthly ministry, or "aliveness," at a time of seemingly enormous potential for social change.

It is this latter question - over the inevitability of fugitive resistance for anyone truly engaged in resistance that was pertinent in Christian circles of the time. Some light is thrown onto such thinking, and tensions, by a longforgotten intervention from David Wilkerson which sought to 
address the spiritual/theological situation of the late 1960s with Purple-Violet-Squish, published in 1969. Wilkerson provides an overview of various counterculture strata via a spirited attempt to speak to his young audience in their own assumed language, and tackling "difficult" subjects (free love, LSD, disrespect for authority, and so on). His position is conservative, and at times highly partisan. At one point he associates the theologian Thomas J. J. Altizer with the mental incapacity that Wilkerson anachronistically notes arises from LSD use (1969: 22-23). Wilkerson is reluctant to accept the notion of "the priest in crisis", to borrow the title of O'Neill's 1968 book, in which Berrigan makes an appearance (129-130), as indexical to a wider crisis: despite the challenges of the times, there is nothing that the structures of the church cannot encompass and accommodate, albeit finessed by a modicum of fraternal free-thinking, as per his own work. Wilkerson's second chapter, "The Yippies," deals with the politicized hippies, with whom Wilkerson also lumps the Black Panthers, anti-colonialists, and Students for a Democratic Society. He associates the whole construction with Hell's Angels and Maoist tendencies in the activist/radical milieu. Wilkerson concludes by quoting an unnamed "liberal university administrator" who claims that at least Communists had a program and so were, relatively, "sensible," and easier to engage with. Then Wilkerson appends some lyrics from the 
West Coast psychedelic group The Jefferson Airplane, (Wilkerson 1969: 33).

This chapter opens with Berrigan's draft card burning. Tellingly, Wilkerson fails to either condemn or praise the act. And yet, like Berrigan, Wilkerson was also an activist the founder of a network of Bible-based help centers for people with drug abuse-related issues, Teen Challenge. Wilkerson's equivocation at least acknowledges and grapples with the new culture in an aspirationally even-handed (even if ill-informed) way. In sharp contrast, the philosopher and journalist Jean-François Revel's parade of caricatures of deluded grotesques dismisses the entirety of the counterculture. Writing in 1970 on "Jesus, Marx and America" (1972: 166-200), Revel despairs at the freeform, post-dogma, pseudo-ecumenical, countercultural religious modishness, of "'Buddhist monks' [...] all natives of Oregon or Arizona [...] [alongside] a 'naturist pantheist' [who] sells fruit and vegetables grown without fertilizer" (180), wielding slogans such as "Zen Marxism"" and "Jesus is the best trip"" (184). Revel uses the pejorative "Jesus Freaks" for the Jesus Movement, and sees the entirely as an outgrowth of the Woodstock music festival, people rubbing shoulders with straddlers in insurrectionary currents, or those fleecing gullible benefactors. The absence of a coherent editorial line in Wilkerson and Revel's slanders indicate that Berrigan's 
action raised questions for Christians of this time of such magnitude and immediacy that they were best left unarticulated or warranted ferocious, "scorched earth" attacks. To begin to take a position, or even sympathize, would be to place oneself in danger of the ruptures and crises that would unavoidably arise from confronting the war in Vietnam as "morally intolerable" (Hạh and Berrigan 2001: 134). ${ }^{9}$ But, at the time, despite Wilklerson's counsel and Revel's condemnations, taking a position, and even intervening, was clearly felt to be unavoidable and indeed essential by younger theologians. The joint-authored Containment and Change of 1967, drawn from debates in February 1966 at the Union Theological Society in New York City, opens with the prompt "Why should Vietnam disrupt Western composure so deeply?" (Oglesby and Shaull 1967: 4) and closes with the thought that

Any hope for a significant Christian contribution to the revolutionary struggles going on around the world will depend, I believe, on the emergence of new forms of Christian community on the front lines of the revolution. [...] It is just possible that in such weak and informal communities new ideas and questions may take shape which will be of significance for the revolutionary movement as a whole; and the resources available for such a struggle may become more visible through such an effort (Oglesby and Shaull 1967: 247). 
In respect of what clearly seemed to be irresolvable tensions in this fledgling theological culture, and as aggravated by the seemingly inexorable escalation of the military brutality visited on the people of Vietnam, the Catonsville action only a few months later may have seemed unsurprising or even inevitable. ${ }^{10}$ The modernizing impulse of Vatican II, of only a couple of years prior, seems to have opened and expanded into the tide of activism around the North American counterculture of 1967-1968. Berrigan was iconic in his use of language and his appearance "looking a little like D. H. Lawrence, which is to say Christ" (Burgess 1971: 3), a "Chairman Jesus" (Berrigan 1973: 63). Such new forms of resistance and new communities would in turn advance beyond Berrigan's positions, developing into the idea of the social role of the church, especially in relation to the theological struggles of Liberation Theology in the 1970s and first half of the 1980s. ${ }^{11}$

\section{"Berrigan Raps"}

The Trial of the Catonsville Nine can be read as an attempt to deepen the theatricality of the Catonsville activism and its aftermath by pushing the act further into public awareness, inviting a consideration of it within a wider culture of resistance. The act, as example, had seemingly proven to be effective. Popowski notes that by October 1970, 250 draft offices had been raided. Wider activities of the Catholic Left, as associated with the 
Berrigan brothers in the popular imagination, included acts of sabotage against military vehicles (2008: 295). Meconis totals the number of draft cards destroyed by the Catholic Left as over a million by March 1971 (1979: 151). (Meconis also compiles a chart and timeline of actions from October 1967 to October 1972; see appendix B, 167). But the act needed to be extended, to generate an institutional critique. Noam Chomsky, considering the Berrigan brothers in relation to activism, noted that "[m]y impression is that actions such as those in Catonsville and Milwaukee might receive broad support, if the effort were made to explain and discuss them. If there has been a serious failing, I think it is in this indispensable second-order effort" (1971: 55). And it is this indispensable second-order effort, of generating awareness, that also goes some way to explaining and justifying what was effectively the media operation or PR arm of Berrigan's actions during these years: while in "hiding" he made public appearances, published letters, essays, poems, collections, even an LP (Berrigan Raps), was the subject of a documentary and innumerable critical books and articles. ${ }^{12}$ Doubleday was particularly keen on Berrigan publications, through the work of commissioning editor Elizabeth Bartelme, and did not hesitate to use terms and images on their dustjackets that may have suggested vain egoism on the part of Berrigan (see Bartelme 1996: 105-108). ${ }^{13}$ As with the Weathermen and their communiques, Berrigan understood that hiding a light under a bushel was an 
ineffective way of intervening in wider society. But Berrigan notes that the light is not one of infernos of draft cards, but one that shows the way to the rebirth of "new men" and new communities analogous to "the early Christians." In 1971 he said "We must create communities"

[...] which themselves become signs of hope, signs that the Holy Spirit is indeed coming upon us. Perhaps these communities, peace affirming, contemptuous of existing powers [...] will be made up of the most diverse people ... It seems to me that 'new men' may well appear in many places and under many guises, and that to be alive to the signs those men offer is to be alive to the true hope that is before us (Berrigan and Coles 2001: 171-172).

The play sought to extract the material from Catonsville to achieve that being "contemptuous of existing powers." To do so required a documenting of an encounter with those existing powers.

The play - nominally documentary theatre rather than fiction, but even then only nominally a play text at all in its 1970 published form (Berrigan 2004) ${ }^{14}$ - seemed to have sought to universalize the historic act of intervention against the machinations of state that occurred in the Catonsville trial. While it would be tempting to consider the play as avant-garde in its construction, it would be difficult to think of any theatrical production from 1970 concerning 
Vietnam that to would not be, to an extent, avant-garde. Berrigan's text is of a piece with the uncompromising, impassioned and sometimes amateur or unpolished political theatre of its moment.

Berrigan provides few to no stage directions. He reworks much of the dialogue of the trial into a kind of blank verse, which at times spatially organizes words or phrases on the page, inviting a delivery from performers that seeks to underscore wider meanings or implications. The play is structured into five sections: "The Day of the Jury of the Peers", "The Day of the Facts of the Case", "The Day of the Nine Defendants", "The Day of Summation" and "The Day of Verdict." The chief concern of the play is showcasing often lengthy speeches from the accused that discuss the reasons for and thinking behind their actions. These speeches are often moral philosophical, political, ethical, legal, civil, and historical positions.

The text of the play itself contains oblique interjections - quotations (without much in the way of citation) from a variety of sources: poems (by Berrigan and others), snippets of political speeches of Thomas Jefferson, Bishop Defregger of Munich, J. Robert Oppenheimer, Fidel Castro, Adolf Hitler, and Ho Chi Minh twice, extracts from Sartre, Camus, Sophocles, Weiss, and Kafka, and handbooks ("Mafia", as Berrigan puts it, Green Beret), other court 
records, and even the court record of this trial (to illustrate the confusion of the presiding judge). Also included are uncaptioned photographs of some of the figures presented in the play and other images of obscure origin. Such interjections, while never explained, or explicitly (or even diegetically) related to the text concerning the trial, are certainly telling. Two plays concerning other victims of Catholic persecution also appear: from Brecht's 1943 Life of Galileo and from Jean Anouilh's 1959 Becket, or the Honor of God. Perhaps these interjections were intended to offer licence and material for Brechtian devices introduced into the performed play by those who would produce it. This would mean breaking from naturalism or realism, maybe using direct addresses to the audience - ways to help the audience situate the play's action in different contexts, showing that the actors are caught in the machinations of a wider system where the judge and even the jury are unwilling or unable to resist the roles society assigns to them.

The showcasing mentioned is a matter of pushing the draft card burning as now extended to the rhetorical stand taken by the nine on trial, to the fore as an example for others. During the sermon seen in The Holy Outlaw, Berrigan talks of his actions as working "so that a solid wall of conscience confronts the death-makers," and that his individual actions should spur on others in the congregation to their own 
actions. A few members of that congregation are interviewed afterwards and seem either stunned or confused. But what of those who did try to follow this example? Meconis gives the Summer of 1970 as the point at which the Catholic Left was at a "virtual standstill" (1979: 76). This was not a matter of a theological impasse, but the tactically disastrous decision to go underground a few months prior which engendered increased police action and harsher regimes for those associates actually imprisoned, problematizing the notion of nonviolent protest, and fatally miscalculating the way in which "the Catholic Left's members possessed neither the know-how nor the discipline to successfully conduct what amounted to urban guerrilla warfare" (Meconis 1979: 146). One of the difficulties in being "against" is that success can only be measured counterfactually and in negative correlation: what then did not occur. Recalling the difficulties of the time many years later, Berrigan notes that the anti-war movement "made it politically impossible to continue the war [...] morally impossible to launch nuclear weapons [... and] helped remove two presidents from office" (quoted in Kisseloff 2007: 117) .

The Trial of the Catonsville Nine, in this context, can be read as opening up a second front against the "deathmakers" on the part of the anti-war movement. This is discussed in terms of PR, above - and, certainly, there would 
have been the need to educate both the curious and disinterested as to the nature of the Catonsville action and the state response to it, as Chomsky claims. But clearly the trial itself is presented as folded into the action - as the Second Act of the engagement with the state or, in dialectical terms, its antithesis - with a thesis (burning draft cards), antithesis (arrest and trial), and anticipated synthesis (public outrage and further anti-war actions). In this respect, and in keeping with the principals or discipline necessary for nonviolent action, and indeed acknowledging the talkiness of the text, The Trial as theatre is intellectual rather than emotional. In "Father Berrigan Speaks to the Actors from Underground," Berrigan notes that the play "launched" (as if an expedition into the unknown) on "our behalf" (that is, on behalf of those underground) "might speak to people, might bring them to a more accurate, realistic, and painful sense of things" (Berrigan 1973: 87).

Berrigan then talks in his letter to the actors preparing a production of his "envy" of what was then the premiere countercultural theatre troupe, The Living Theatre. During the late 1960s, the audience would become immersed in the Living's freeform, hedonistic (often involving hallucinatory drugs and sexual encounters), law-testing or -breaking performances including confrontations with authorities who found themselves effectively cast as antagonists. And yet, unlike Berrigan's 
notion of constructing a "solid wall of conscience", the Living Theatre was busy deconstructing all walls and raising consciousness about the new society that would exist beyond restraints: free, communal, nonviolent, utopian. And the Living's performances were therapeutic too: the theatre was cleansing the population of its bad karma or "vibrations," returning re-charged citizens to their protest activities healed of state intimidation and violence. Thus the Living Theatre waged a kind of psychic warfare on the society of the "death-makers". Later, Berrigan recalls another direct encounter with contemporary theatre: his seemingly audacious escape from the FBI agents during his appearance at Cornell University, hidden in one of the giant puppets belonging to the Bread and Puppet Theatre.

For Berrigan, pointedly, the Living Theatre engenders "a common discipline, a common view of the world, a common politics, and above all perhaps of a common linking love that grants an exciting, innovative character" (Berrigan 1973: 88). In short: in the crucible of this collective experimentation, and with and through heightened communication and understanding, comes a new community. Despite the proviso that the community may be finite in duration, or that each instance may be finite, Berrigan notes "some sense of the depth, inwardness and communality" (1973: 88) is achieved. To find such a view via the seemingly amoral hippy masses required, 
from a Catholic priest, an expanded view of morality and a bold venturing out into the counterculture.

\section{To Actors, to Audiences}

"Father Berrigan Speaks to the Actors from Underground" begins, after an initial greeting and the above-noted intentions for the play, with an observation on Berrigan's part that, despite the "befouled and violence-ridden atmosphere in which [...] young people are coming into adulthood," to his surprise he nevertheless finds "communities arising very quickly," which he also refers to as "teams or caucuses" (1973: 87). For individuals who find themselves "lowered" into the world, and so presumably are prey to the perils of such a fallen environment, such communities offer "a new way of getting born in the world" which he then likens to "the first morning of the creation of the first man" (1973, 87-88). Everything, then, awaits, and everything seems possible through such a remaking. Berrigan notes that the Catonsville action arose from a sense of leaving innocence for experience, paraphrasing William Blake. The parallel is with resurrection: to reject the living death of life in contemporary North American society, to die from that society in order to be reborn in a new way. And this dying can be both literal (as with Brother David Darst, a member of the Catonsville Nine killed in a car crash) and professional 
(rejecting polite society, going underground, finding or forming new communities).

From this vantage point, the play becomes clear: those who died and have been reborn are talking to those who are alive but represent a kind of living dead. Contemporary American theatre seemed to have found a position on this spectrum too: entertainments on and off Broadway which, for Berrigan, are "sprayed with the false front of frivolity, amnesia, anomie [...] are infantile [...] retard[ing] the moral sense of man" and are thus "escapism" (1973: 89-90). Berrigan's theatre is one of awakening rather than lulling the audience, to "help American get born, get going, get growing [...]" (1973: 89). To awaken audiences is the role of the actors. Their "moral passion and bodily gestures" can channel what Berrigan calls "spirit" and "human spirit," a zest and authenticity, or spiritedness (in the sense of a "spirited" person). As a poet, Berrigan carefully weighs his words, and while spirit suggests spiritual, the very opposite position seems to be Berrigan's preferred interpretation: not to be otherworldly, but to be deeply physically embedded in the moment, as with Pasolini's walking Christ, as with the condition of being underground. For Berrigan, the spirit is the almost tactile presentness of others, audiences encountering actors in the same space. ${ }^{15}$ 
For the actors, this spirit is found "creating and communicating light around their bodies." This comes from being interlocutors for absent others: listed by Berrigan as those in prison, or underground, or exiled. Or what is said by those "in death." In terms of The Trial of the Cantonsville Nine, such a connection is easily grasped: they speak the words of/for absent others, including the underground playwright. In this, the jarringly oblique interjections in the play text can be accounted for: "live" quotations that give voice to historical figures and their ideas or articulations. But in all this, which involves the "voice of a generation" speaking the Zeitgeist (in the manner of Bob Dylan, say), the suggestions Berrigan makes are difficult and singularly impractical, or even counterproductive, for actors preparing

An additional role for the actors is noted as the "tightening of crisis" for those who stood "in a circle of imaginative protection," a vantage point from which everyone is "facing together the consequence of crisis" (1973: 90). Tightening would seem to be a matter of articulating the wider crisis for the purposes of distilling its essence or essences: heightening the unavoidable nature of its consequences. The play, after all, simply concerns (from a narrative point of view) consequences. And in this respect of tightening, the conceptualization of theatre is related closely to Berrigan's 
position: "in such a way a link is closed between what you are doing onstage and what I am trying to do in the underground", which is "hottening things up [...] and then extending our reach so that we are not the only ones saved; so that others get in and under and away with us" (1973: 90). Thus crisis, and a painful sense of things, and of alteration, are in the offing. And the talk of heat and tightening, of circles and light, suggest a possible mise-en-scène and/or production design of closeness and discomfort, not allowing an audience to hide from the action and its implications by retreating into the darkened recesses of the theatre space, or treating the performance as self-contained and over once the particular performance has ended.

Berrigan concludes this matter with: "So the connection between resistance and the theatre ought to be pondered not merely by actors but by the relationship they strive to establish with their audience as well as by the kind of audience they attract" (1973: 89). He also warns the actors that the experience of working with this text will result in "changes" in them "of a rather serious order" (1973: 90). One would assume the change is one of enlightenment: that the actors will effectively communicate the nature of pacifist activism as a critique of war-mongering, and awaken the implications for society at large. Berrigan notes that such changes may occur in the audience too. ${ }^{16}$ 
In the coda to the letter, "And to the Audience," Berrigan conceptualizes the audience as "spectators at events, crises, dramas" who need a galvanizing change (1973: 90) . Berrigan notes that this was the state of "us": the Catonsville group, who were once unenlightened too. But the process that enabled the Catonsville action was one of being purged of fears of punitive consequences of actions in violation of laws. The widely-circulated images of Berrigan in handcuffs, as per Berrigan Raps, even prompted the Weather Underground to proclaim that, "smiling and with hands raised [...] [y] ou have refused the corruption of your generation" ([1970] 2006: 156). Purging is also the modus operandi of the play: to push the audience away from pity and to, seemingly, a clear-headed appreciation of the wider situation and the actions to be taken. The distillation of crisis is presumably to these ends. And the purging results in a freedom from fear, and so a freedom to act, unshackled by societal propriety, as per the example of the Catonsville Nine. Thus "pity" and "fear" are the "inhabiting demons" of the audiences' hearts, (1973: 93). Pity would seem to be a major moral virtue in a Christian context, and it is odd that Berrigan would talk of the need to exorcise it. Nor is it clear whether pity, found in "the veins of the mind" (1973: 91) refers to pity for others, or self-pity. And pity would seem to be the quality that motivated Berrigan to act, before and after Catonsville: pity for victims of US aggression, most notably in his 
excoriating and stunning 1968 poem "Children in the Shelter," in which Berrigan recalls cradling a child victim of a U.S. bombing raid while in Vietnam, described, perhaps blasphemously, as "the messiah/of all my tears", and "a Hiroshima child from hell." The implication is that U.S. aggression in Vietnam is of a piece, or in continuum, with Herod's infanticide, and the atomic bomb, hell on earth. Pity for the victims seems the only human response. But then pity is a condition of immobility. Pity disables action, or waylays anger. To act requires leaving such a cul-de-sac.

This positioning of the audience, or identification of its character, suggests a further movement away from "spiritual" qualities of empathy to a pressing awareness of and material grounding in a sense of immediate reality. The audience that needs to be brought back down to earth were presumably an audience of everywo/men: not those associated with the underground, not activists, but those of the everyday overground, living in ignorance. Such an intellectual engagement is quite different from the Living Theatre, and the kind of theatre created under the aegis of Artaud during those years. In this, "dropping out" (both psychologically via hallucinogenics and societally via dropping out of a repressive and repressed society) was the way in which change was to be enacted: a shift in consciousness rather than conscience - although the shift in conscience would clearly 
follow. But even then, those who attended the Living Theatre in the late 1960s were probably already sympathetic to alternative lifestyles (and so not so beset by the devils of pity or fear), or fully conversant in alternative lifestyles, rather than "squares" or "plastic people" inadvertently encountering a life-changing experience. To be "out of it" is for Berrigan akin to escapist theatre: intellectually and politically disengaged, and so stunting the growth of selfawareness. And a further analogy suggests itself: to be "out of it" in terms of monastic life. As an outsider, Berrigan expressed distance from the methods of the Living Theatre, which he found simplistic, degrading, and threatening, an invasion of human dignity (Riemer 1971: 62-63). Bluntly, "[w]e're going to have to have a different theatre than that, I think" (quoted in Riemer 1971: 62).

Berrigan's audience of everywo/men is therefore the world at large. And, indeed, Berrigan's engagement with theatre was only one aspect of his life whereas for the Living Theatre, it was everything. Berrigan's world consists of "our friends and hearers and audience and jury." The purging of the audience, as experienced by the Catonsville Nine, transubstantiates the activism by means of the play which is an affective experience for the audience. The audience is conceived as partially, in their everywo/man ignorance, hostile. After all, "they" are related to the jury who did not understand, and were clear in 
their guilty verdicts (as recorded in the play). But unlike the juridical audience, the theatre audience, once exorcised of their demons, will return to the world from which they were drawn, changed. In this respect the play, and Berrigan's conception of a radical theatre, is understood as a missionary action: an incursion into the hostile (overground) territory of those yet to be civilized.

Thus, on the cultural front, Berrigan posited two kinds of possible otherworldliness for the Catholic Left and fellow travellers. One was arguably idealistic, and possibly doomed to failure, but nonetheless an incubation for a new society and a regeneration of the spirit, albeit at the expense of jail. This was the world of the underground. The other was an immobilizing of subjective responses, such as pity, enabling coexistence with war. These were the options available. Father Berrigan's voice, from underground and through the theatre, asked: which do you choose?

References:

Ayers, B. [2001] 2009. Fugitive Days: Memoirs of an Antiwar Activist. Boston: Beacon Press. 
Bartelme, Elizabeth. 1996. "A Poet for Difficult Times." In Daniel Berrigan: Poetry, Drama, Prose, edited by Michael True, 105-108. New York: Orbis Books.

Bates, Stephen. 2011. "Church of England Split over St Paul's Handling of Occupy London Protest." The Guardian, 27 October. Accessed 1 November 2016.

www.theguardian.com/uk/2011/oct/27/church-st-pauls-occupylondon

Berrigan, D. [1970] 2004. The Trial of the Catonsville Nine. New York: Fordham University Press.

Berrigan, D. 1971. The Dark Night of Resistance. New York: Doubleday \& Company, Inc.

Berrigan, Daniel. 1971. "From Underground, Father Berrigan Speaks to Actors." New York Times (Arts and Leisure section), 31 January: D1.

Berrigan, D. [1972] 1973. America is Hard to Find: Notes from the Underground and Letters from Danbury Prison. SPCK: London. Berrigan, Daniel. [1978] 1988. "Letter to Ernesto Cardenal: Guns Don't Work." In Daniel Berrigan: Poetry, Drama, Prose, edited by Michael True, 166-170. New York: Orbis Books. Berrigan, D. and R. Coles. 2001. The Geography of Faith: Underground Conversations on Religious, Political and Social Change. Vermont: Skylight Publishing . 
Bianchi, E. C. 1972. The Religious Experience of

Revolutionaries. New York: Doubleday \& Company, Inc.

Brown, Robert McAfee. 1971. "The Berrigans: Signs or Models?"

In The Berrigans, by Willian Van Etten Casey SJ and Philip

Nobile, 60-70. New York: Avon.

Burgess, Anthony. 1971. "More McLuhan than God." Chicago

Tribune ("Book World" supplement), 2 May: 3.

Casey SJ, W. V. E. and P. Nobile, editors. 1971. The

Berrigans. New York: Avon.

Chomsky, Noam. 1971. "On the Limits of Civil Disobedience." In The Berrigans, by Willian Van Etten Casey SJ and Philip Nobile, 37-59. New York: Avon.

Crow, Earl. 1996. "Humanity and Humor." In Apostle of Peace: Essays in Honor of Daniel Berrigan, edited by John Dear, 6771. New York: Orbis Books.

Davidson, Gordon. 2005. "Formative Moments in a Theatrical Life." Lectured and discussion at All Saints Church, Pasadena, 27 February. Accessed 1 Augusts 2016. Www.allsaintspas.org/modules/toc/uploads/files/aid944_formative_moments_in_ 46b5669b_2eb3_4029_u1.pdf

Dohrn, Bernardine, Weather Underground. [1970] 2006. "New Morning - Changing Weather." In Sing a Battle Song: The Revolutionary Poetry, Statements, and Communiques of the 
Weather Underground, 1970-1974, edited by Bernardine Dohrn, Bill Ayers and Jeff Jones, 161-169. New York, Toronto, London, Melbourne: Seven Stories Press.

Goddard, M. 2017. Guerrilla Networks: An Anarchaeology of 1970s Radical Media. Amsterdam: University of Amsterdam Press. Hạnh, T. N. and D. Berrigan. [1975] 2001. The Raft is Not the Shore: Conversations towards a Buddhist-Christian Awareness. New York: Orbis Books.

Isaac, Dan. 1971. "Theatre of Fact." The Drama Review 15,3: $109-135$

Jenkins, P. [1979] 1983. A Walk Across America. Herts, England: Lion.

Jeannot, Thomas. 2002. "Berrigan Underground." In Faith, Resistance, and The Future: Daniel Berrigan's Challenge to Catholic Social Thought, edited by James L. Marsh and Anna J. Brown, 155-182. New York: Fordham University Press.

Kisseloff, J. 2007. Generation on Fire: Voices of Protest from the 1960s. Kentucky: The University Press of Kentucky. Klejment, Anne. 1988. "War Resistance and Property Destruction: The Catonsville Nine Draft Board Raid and Catholic Worker Pacifism." In A Revolution of the Heart: Essays on the Catholic Worker, edited by Patrick G. Coy and Jim Douglass, 275-312. Philadelphia: Temple University Press. 
Meconis, C. A. 1979. With Clumsy Grace: The American Catholic Left, 1961-1975. New York: Continuum.

O'Connor, J. 2013. Documentary Trial Plays in Contemporary American Theater. Carbondale and Edwardsville: Southern Illinois University Press.

Oglesby, C. and R. Shaull. 1967. Containment and Change. London: Collier-Macmillan Limited.

Olzen, Jake. 2013. "How the Catonsville Nine Survived on Film." Waging Non Violence, 17 May. Accessed 1 July 2016. http://wagingnonviolence.org/feature/how-the-catonsville-ninesurvived-on-film/

O'Neill, D. P. 1968. The Priest in Crisis: A Study in Role Change. London, Dublin, Melbourne: Geoffrey Chapman. Polner, M. 1998. Disarmed and Dangerous: The Radical Life and Times of Daniel and Philip Berrigan, Brothers in Religious Faith and Civil Disobedience. New York: Westview Press / Perseus.

Popowski, M. D. 2008. Roman Catholic Crusading in Ten Years of Triumph, 1966-1976: A History of a Lay-Directed Radical Catholic Journal. Unpublished PhD thesis, Oklahoma State University •

Revel, J.-F. [1970] 1972. Without Marx or Jesus: The New American Revolution Has Begun. London: Paladin. 
Riemer, G. 1971. The New Jesuits. Boston, Toronto: Little, Brown and Company.

Roberts, R. E. 1971. The New Communes: Coming Together in America. Englewood Cliffs, New Jersey: Prentice-Hall, Inc.

Rudd, M. 2009. Underground: My Life with SDS and The Weathermen. New York, London, Toronto, Sydney: Harper.

Sacred Congregation for the Doctrine of Faith. 1984.

Instruction on Certain Aspects of the "Theology of

Liberation". Boston: St. Paul Books \& Media. Also available via

wWw.vatican.va/roman_curia/congregations/cfaith/documents/rc_c on_cfaith_doc_19840806_theology-liberation_en.html. Accessed 1 July 2016.

True, M. editor. 1988. Daniel Berrigan: Poetry, Drama, Prose. New York: Orbis Books.

Weather Underground, The. [1970] 2006. "Message to Daniel Berrigan." In Sing a Battle Song: The Revolutionary Poetry, Statements, and Communiques of the Weather Underground, 19701974, edited by Bernardine Dohrn, Bill Ayers and Jeff Jones, 155-156. New York, Toronto, London, Melbourne: Seven Stories Press.

Wilkerson, D. 1969. Purple-Violet-Squish. London: Oliphants / Zondervan Publishing House. 
1 "To the Actors...", as it will be termed hereafter, was later included in the 1988 collection Daniel Berrigan: Poetry, Drama, Prose, retitled "To the Actors, from Underground" and described as an essay, as one of the eight collected pieces covering his trial, "underground" period, and imprisonment. The volume's editor, Michael True, concludes his Preface by noting that "For anyone who has published so much, the quality of his writing will often vary, and in previous reviews of his work I have mentioned that Daniel Berrigan needs an editor, not knowing that I would eventually wind up in such a position" (True 1988: xiii). The inclusion then of a truncated version of "To the Actors..." (its short and crucial coda, addressed to the audience, was removed), is nevertheless indicative of its importance in Berrigan's oeuvre.

2 For further details, see Polner's 1998 joint biography of the brothers Daniel (born 1921) and Philip Berrigan (1923-2002) . On the matter of Daniel Berrigan's legal status, in relation to nonviolent activism and its implicit critique of law, see Jeannot (2012).

3 The footage is available:

https://www.youtube.com/watch?v=d3NM3xaNuLk (accessed November 2016). For the backstory of the filming see Olzen (2013). And the footage itself was the central concern of Lynne Sachs's 2001 documentary Investigation of a Flame. 
4 In True's collection of Berrigan's writings, "Letter to Actors..." is followed by the "Letter to the Weathermen", first published in The Village Voice in January 1971 (282-297), as per the ordering in America is Hard to Find. Recent memoirs by Weathermen, which detail life underground, explicitly connect fugitive existence with armed insurrection; see (Ayers 2009 and Rudd 2009). In the documentary Holy Outlaw, discussed below, Berrigan suggests or volunteers himself as an appropriate figure to be the official Chaplain of the Weathermen who, like himself at that time, were fugitives. The Weatherman, writing publically to "Brother Dan" upon his final arrest, urged him to "join us soon"; (Weather Underground, $2006[1970]: 155,156)$.

Moylan immediately joined the Weather Underground upon absconding; she is mentioned in the Weatherman 6 December 1970 communique "New Morning - Changing Weather" (Dohrn, Weather Underground 2006: 161-169). Film-maker Emile de Antonio interviewed Berrigan for the documentary In the Year of the Pig (1968); he filmed the Weather Underground for the documentary Underground (1976, directed by de Antonio, Haskell Wexler, and Mary Lampson); then he had the Berrigan brothers play themselves in a dramatization of another trial resulting from a subsequent anti-war action In the King of Prussia (1983). One can only assume that Berrigan, like Moylan, envisaged a reformist role in the Weather Underground. In 
1970, he recorded that he was "appalled" by their violence; (Riemer 1971: 55).

5 The Electric Prunes and David Axelrod, Mass in F Minor, Reprise Records. The music, which melds faux-Gregorian chant with "acid" guitar jams, was used in part for Easy Rider. 6 The film was broadcast in 1970 on the National Education Television ("NET") network, and had an afterlife of university campus screenings (for example: five screenings on Friday 4 December 1970 at the University of Kansas School of Religion, "sponsored by the University Christian Movement"). The film has long since fallen into obscurity.

7 For further conversation from the underground period, see (Berrigan and Coles 2001) and Riemer (1971: 37-63). Riemer is understandably guarded regarding the precise date of their extended discussion.

8 Formative theological writers and/or figures for Berrigan include Paul Tillich, Dietrich Bonhoeffer, Martin Luther King, and his friend Thomas Merton, as well as the French workerpriest movement and his encounters with the Catholic Worker (on the latter, see Klejment: 1988, 275).

9 The publication The Berrigans (Casey and Nobile, 1971), an expanded version of the January 1971 special issue of New Cross Quarterly, "The Burden of the Berrigans" (which had then been much in demand and elicited substantial correspondence) sought to represent a more informed engagement with the 
Berrigans' actions, albeit with respect to debates firmly within the Catholic Church. The mass of critical writing rapidly generated around the Berrigans, and the Catholic Left in general, is apparent in a 1971 introductory bibliographic note by Robert Coles to The Geography of Faith (Berrigan and Coles 2001: 32).

10 And indeed Richard Shaull, earlier in Containment and Change, elaborates on such a position in a way that closely anticipates the Berrigans" actions: that a "political equivalent" of "guerrilla warfare" is necessary, based on institutional critique: "The focus here is on the formation of small groups and movements which, whether based inside or outside an institution, force it to accelerate its own renewal. By means of many limited attacks at various points, a small group of people may be able to liberate large institutions for more effective service" (Oglesby and Shaull 1967: 196). A recent example of this came in 2011, with the occupation of St Paul's Cathedral by the Occupy London group and the public splintering of the official response from the Church of England (see Bates 2011). This strategy allows for an evolving institutional critique in keeping with Revel's diagnosis of a post-dogma mindset, and Berrigan's airy preference for "a group of worshipping Christians, not necessarily Catholics." 
11 That is, if one dates the formal close of these struggles with the publication of Instruction on Certain Aspects of the "Theology of Liberation" (Sacred Congregation for the Doctrine of Faith 1984). Berrigan's own engagement with Liberation Theology is reflected in the film The Mission (Roland Joffe, 1986) -- a movie about a semi-fictional mission in Paraguay in the 1740s. Berrigan, who appears in the film in a non-speaking role, advised the film-makers. He sides with those Jesuits who engaged in a fatal non-violent protest rather than with those who take up arms to protect the mission. This position against militant action set Berrigan apart from his milieu even in 1969. In comments made in the Introduction to the Catonsville play he concludes that "... by June, I was old hat." (Berrigan 2004: xix) The same falling out of favor with the vanguard occurred to the Living Theatre too, as discussed below, also around 1969, in relation to their pacifist stance. Brown notes that the Berrigans spent "inordinate amounts of time" during the Catonsville trial attempting to "cool" down their agitated supporters outside, "to avoid inciting violence or provoking it" (Brown 1971: 65). For Berrigan's direct thoughts on armed resistance (in relation to Fr. Ernesto Cardenal's support for the Sandinistas), see (Berrigan 1988: 166-170). 12 The LP was advertised as free with mail order purchases of the Trial of the Catonsville Nine LP - "an exciting album that presents an intimate portrait of Berrigan as a man and as a 
radical." It was also released by Caedmon Records. The sleeve notes were taken from Riemer's 1971 interview, a picture of Berrigan in handcuffs, giving a peace sign, is on the cover. The album consists of "A Sermon from the Underground", an interview, and poetry readings. "Raps" in this context referred to in-depth and meaningful talk ("Let's rap") rather than a style of semi-spoken music.

The Weather Underground also developed and maintained a PR operation, along similar lines of propagating their message, especially in countering a uniformly hostile mainstream mass media. For a full discussion of this strategy on their part, see Goddard (2017).

13 The question of pride is discussed at length, and very directly, by Berrigan and Coles (2001: 60-75). For Coles, "[...] the adulation and devotion someone like you gets from a number of people elevates you and puts you in a position of leadership [which is] potentially corrupting. [...] I ask you again about the sin of pride, something every leader, every innovator, every charismatic person presumably has to struggle with especially hard" (2001: 60-61). The Berrigans appeared on the cover of Time magazine on 25 January 1971. Berrigan mentions elsewhere (Riemer 1971: 38) that maintaining a public profile prevented him from being expelled from the Jesuit order which would have damaged his activist credibility as well as allowing the order to distance itself from anti-war 
sentiment and activism in general. In interview with Riemer, Berrigan asserts that senior Catholic clerics who spent their time with President Richard Nixon and combat-active troops rather than with prisoners or becoming involved in the antiwar movement, "betray the church" (47).

14 Berrigan "changed only slightly" the 2004 publication; according to Robin Andersen he "rewrote various passages" (see (Berrigan 2004: xvi). Other variants do exist. The text of the Off-Broadway version was hewn by playwright saul Levitt from the longer, original text (see O'Connor 2013: 36, 42-43 and 191, footnote 9). Isaac, writing in 1971, refers to the play text as a "foreshortened reshaping" rather than "exact transcription take from the court record" (1971: 124). My discussion of the play draws on the 2004 edition. The balance of what has been "worked into" the play from court transcripts, or Berrigan's recollections, or via a based-onreal-events dramatization, is unclear, although Berrigan notes in his Introduction a fidelity to the "original words" from the court stenographer (Berrigan 2004: xvii). O'Connor notes that versions of the play do not remain "strictly faithful to the courtroom procedures", and revisions to the play included composite testimonials, for dramatic brevity (O'Connor 2013: $42-43)$

15 Ironically, the absent Berrigan seems to have been very present in some performances, a "spiritualist" disembodied 
voice "from the other side." Davidson recalled that the New York production began with a tape recording he had made of Berrigan (from a "safe house"), which was played to the audience over a Public Address system before the play began with the house lights half-dimmed. The recording began: "This is Father Berrigan speaking from the underground." This prompted alarmed members of the FBI hidden in the audience to immediately and hopelessly search the premises for the fugitive Jesuit (Davidson 2005) . 16 Berrigan posits a connection to classical Greek drama including the problem of pity, but idiosyncratically interprets the mimesis of Greek theatre as "an act of remembrance" (presumably of the trial, which itself became an act of remembrance of the action) rather than, as is more typically understood, a form of mimicry or representation of the world. 